\title{
Study on methodology for the assessment of internal and marginal adaptation on fixed dental prosthesis
}

\author{
Se-Wook Pyo, Jun-Jae Lee, Jung-Suk Han, Young-Jun Lim* \\ Department of Prosthodontics and Dental Research Institute, School of Dentistry, Seoul National University, Seoul, Republic \\ of Korea
}

This article is to review various methods used to investigate internal and marginal adaptation of fixed dental prostheses, and to summarize a merit, worth, and limitation of each method, using some results of previous studies. The methods of measuring internal and marginal gap are divided into two categories in this study; in vivo and in vitro. In vivo methods are clinical evaluations, including exploration, radiography, and impression technique. In vitro methods are laboratory evaluations such as direct view, crosssectioning, and silicone replica technique using microscope. Measuring by micro computed tomography (CT) or profilometer is also in vitro methods. In recent years, the development of scanning systems is able to analyze 3-dimensional internal and marginal space in detail. As measuring and analyzing technology become more advanced, the ability to thoroughly examine crown adaptation is becoming both simpler and more efficient. (J Dent Rehabil Appl Sci 2016;32(3):158-68)

Key words: marginal fit; internal fit; crown adaptation; fit measurement

\section{서론}

치과의사가 보철물을 시적할 때에는 일반적으로 인접 면 검사, 내면 및 변연적합도 검사, 교합검사를 반드시 해 야 한다. 인접면이나 교합면과 같은 외형적인 요소들은 보철물이 제작된 후 어느 정도 조정이 가능하지만, 내면 과 변연의 적합도는 보철물 제작 과정에서 이미 결정되는 만큼 그 보철물의 예후를 결정하는 가장 중요한 요소라 고 할 수 있다. 보철물의 적합도는 내면적합도부터 평가 하는데, 내면에 먼저 닿는 부분이 존재하는 경우에 보철 물이 완전히 들어가지 않아 변연부를 정상적으로 평가할 수 없기 때문이다. 따라서 기공 과정에서 내면적합도 향 상을 위한 적절하고 균일한 시멘트 공간에 대한 고려가 필수적이며, 너무 과도한 내면공간은 보철물의 파절, 탈 락 등을 야기 할 수 있고, ${ }^{1}$ 너무 작은 내면공간은 보철물

\footnotetext{
*Correspondence to: Young-Jun Lim

Professor, Department of Prosthodontics and Dental Research Institute, School of Dentistry, Seoul National University, 101, Daehak-ro, Jongno-gu, Seoul, 03080, Republic of Korea

Tel: +82-2-2072-2940, Fax: +82-2-2072-3860, E-mail: limdds@snu.ac.kr

Received: August 29, 2016/Last Revision: September 9, 2016/Accepted: September 19, 2016
}

의 장착을 불완전하게 할 수 있음을 반드시 숙지해야 한 다. ${ }^{2}$ 내면적합도가 확인된 후에는 보철물과 지대치 경계 부위의 연속성을 확인하여 보철물의 변연 부위가 임상적 으로 적합한지 평가해야 한다. 변연적합도가 좋지 않은 경우 보철물 내면의 시멘트 용해를 촉진시켜 치아와 치 주조직에 부정적인 영향을 주게 되는데, 예를 들면 보철 물 주변으로 치태가 축적되고 치은 염증을 유발할 수 있 으며, 나아가서는 지대치에 2차 우식이나 치수염을 일으 키게 되어 보철물이 실패하는 주된 원인이 된다..$^{3-6}$

하나의 보철물을 제작하기 위해서는 치아 삭제 및 인 상채득 과정을 거쳐 모형을 제작하고 다이 작업을 통해 지대치 모형에 원하는 모양의 납형을 형성한 다음 이를 매몰, 주조하여 완성하는 많은 단계를 거치게 된다. 이런 과정에서 생기는 작은 오차들이 모여 보철물의 최종적인 정확도를 결정하게 된다. 따라서 어떤 단계에서 어느 방

Copyright@ 2016 The Korean Academy of Stomatognathic Function and Occlusion. (c) It is identical to Creative Commons Non-Commercial License. 
법을 사용하는지 결정하는 것이 중요하며, 오랜 기간동 안 이와 관련된 여러 가지 실험들이 이루어져 왔다. 이 실 험들의 목적은 대부분 지대치와 보철물 사이의 변연적합 도(marginal fit) 및 내면적합도(internal fit)를 측정하여 보철물을 평가하고 이를 바탕으로 어떤 단계에서 오차가 생겼는지 파악하는 것이다. 이러한 실험을 계획하기 위 해서는 가장 먼저 보철물의 변연 부위와 내면 부위가 정 확히 어느 지점을 의미하는 것인지 그 정의에 대해 알아 볼 필요가 있다. 이론적으로는 지대치 표면과 제작된 보 철물 사이에 어떠한 간격도 생기지 않고 정확하게 적합 되는 것이 가장 이상적이다. 하지만 실제로는 제작과정 에서 발생한 오차에 의해 내면에 미세한 틈이 생길 수 밖 에 없다. 또한, 시적의 편의성을 위해 지대치 모형에 다이 스페이서를 통한 약간의 공간을 일부러 부여하기도 하 는데 이는 보철물의 합착에 사용되는 시멘트를 위한 공 간이다. 이 두 가지 원인에 의해 발생한 보철물의 내면으 로부터 지대치의 표면까지의 공간을 보철물의 내면 간격 (internal gap)이라고 하며, 그 중에서 가장 치은 측에 가 까운 부분을 변연 간격(marginal gap)이라고 한다. 1989 년 Holmes 등은 보철물과 지대치의 변연적합도 평가 에 대해 언급하면서 내면 간격, 변연 간격, 수직변연간극 (vertical marginal discrepancy), 수평변연간극(horizontal marginal discrepancy), 절대변연간극(absolute marginal discrepancy)이라는 용어를 다음 Fig. 1과 같이 설명 하였다. ${ }^{7}$ 내면 간격은 보철물 내면으로부터 지대치 축 벽까지의 수직거리(a)이고, 변연 간격은 같은 방법으 로 변연부에서의 수직거리(b)를 의미한다. 과도한 크기 (overextended margin)나 부족한 크기(underextended margin)의 보철물에서는 정상 크기 보철물과 달리 변연 부에서의 과부족 길이 $(\mathrm{c}, \mathrm{d})$ 가 발생하게 되는데, 이로 인 해 변연 간격(b)과 절대변연간극 $(\mathrm{g})$ 의 차이가 생기게 되 는 것이다. 절대변연간극의 수직벡터성분을 수직변연간 극(e), 수평벡터성분을 수평변연간극(f)이라고 한다.

임상적으로 받아들여질 수 있는 내면간격과 변연간 격의 크기에 대한 연구는 이전부터 계속 시행되어 왔다. 미국 치과협회(American Dental Association)는 $\mathrm{ADA}$ specification No.8을 통해 보철물의 내면간격이 ZPC (zinc polycarboxylate)를 기준으로 $25-40 \mu \mathrm{m}$ 가 적당하 다고 언급하였고, ${ }^{8}$ Ostlund는 이상적인 내면간격이 25 $\mu \mathrm{m}$ 이므로 절대변연간극은 $50 \mu \mathrm{m}$ 를 넘지 말아야 한다고 주장하였으나, ${ }^{9}$ 이 수치들은 사실상 실현가능성이 낮다 고 할 수 있다. 임상적으로 적절한 변연 간격에 대해 언급 한 연구들을 살펴보면 Sulaiman 등은 $100 \mu \mathrm{m},{ }^{10} \mathrm{McLean}$ 과 Frauenhofer는 $120 \mu \mathrm{m},{ }^{11}$ Gulker는 $200 \mu \mathrm{m}$ 까지도 수 용 가능한 수치라고 보고하였고, ${ }^{12}$ Moldovan 등은 변연 간격이 $100 \mu \mathrm{m}$ 인 것은 "good"으로 $200-300 \mu \mathrm{m}$ 인 것 은 “acceptable"로 분류하였다. ${ }^{13}$

지금까지 언급한 변연 및 내면적합도를 실험적으로 어 떻게 측정할 것인지에 대해 그동안 많은 연구를 통한 다 양한 방법들이 제시되었지만, 아직까지 어떤 방법이 가장 좋은지에 대해서는 의견이 분분하다. 따라서 이 논문에 서는 보철물의 내면 및 변연적합도를 측정하는 여러 가지 방법에 대해 소개하고, 각 방법의 장단점은 무엇인지 알 아보고자 한다.

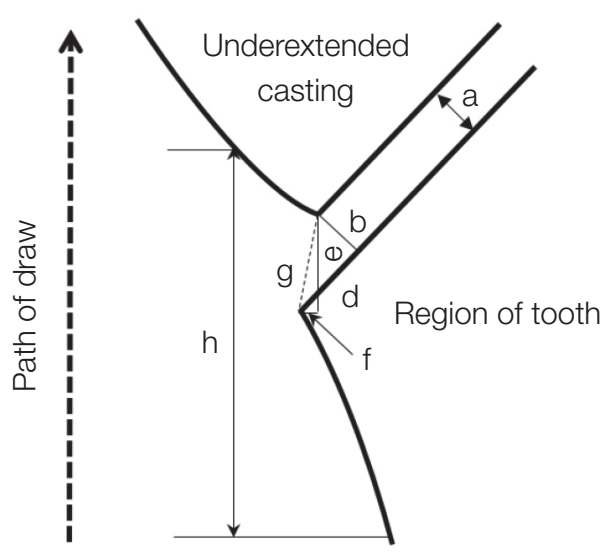

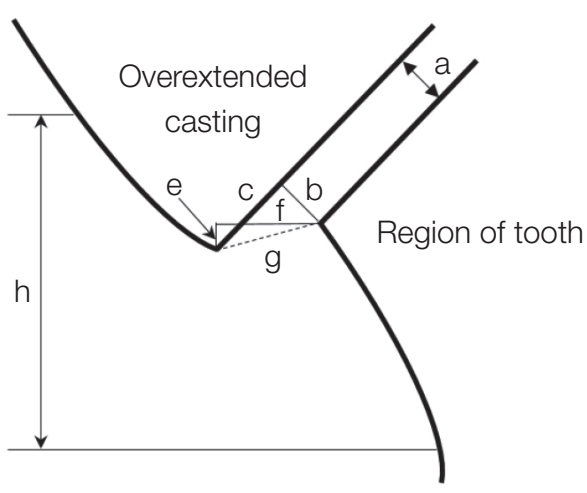

a. Internal gap
b. Marginal gap
c. Overextended margin
d. Underextended margin
e. Vertical marginal discrepancy
f. Horizontal marginal discrepancy
g. Absolute marginal discrepancy
h. Seating discrepancy

Fig. 1. Casting misfit terminology. 


\section{문헌고찰}

보철물의 적합도 실험과 관련하여 1990년 Sorensen은 직접 보는 방법, 절단하여 보는 방법, 인상채득을 통한 방 법, 탐침에 의한 시각적 검사로 분류할 수 있다고 하였 다. ${ }^{14}$ 1993년 Molin과 Karlsson 등은 골드 인레이와 세라 믹 인레이의 적합도 비교를 위해 실리콘 레플리카 테크 닉(replica technique)을 처음으로 사용하였고, ${ }^{15}$ 2009년 Pelekanos 등은 지대치와 보철물을 마이크로 computed tomography $(\mathrm{CT})$ 로 촬영하여 단면 영상을 통해 변연 및 내면 간격을 측정하는 방법을 소개하였다. ${ }^{16}$ 최근에는 스 캐닝 기법의 발달로 모형 스캐너를 이용하여 내면 공간 을 재현한 실리콘 복제물을 3차원적으로 분석한 연구도 발표되었다. ${ }^{17}$ 이러한 다양한 연구들을 바탕으로 임상적 평가법과 실험실 평가법으로 나누어 장단점을 알아보고 자 한다.

\section{1. 임상적 평가법 (in vivo)}

\section{1) 탐침 검사법}

임상적으로 보철물의 적합도를 평가하는 가장 대표적 인 방법은 뾰족한 치과용 익스플로러를 이용하여 변연 부위의 연속성을 검사하는 것이다. 2007년 Hickel 등은 금속주조 보철물을 임상적으로 평가할 때 일정한 기준이 필요하다고 하였는데, 변연부 오차가 $50-150 \mu \mathrm{m}$ 인 경 우에는 변연 부위의 폴리싱 작업을 통해 어느 정도 이상 적으로 조정이 가능하다고 하였다. 변연부 오차가 150 $250 \mu \mathrm{m}$ 인 경우에는 익스플로러를 통해 쉽게 탐지가 가
능한데, 이 경우 보철물과 치아 경계부의 미세누출과 변 색 가능성은 있지만 장기적으로는 크게 부정적인 결과를 가져오지 않는다고 하였다. 반면, 변연부 오차가 $250 \mu \mathrm{m}$ 이상인 경우에는 보철물을 새로 제작하는 것이 추천된다 고 하였다. ${ }^{18}$ 이 탐침 검사법은 보철물의 변연부를 평가하 는 가장 오래된 방법이지만, 각 검사자의 주관적인 평가 가 개입될 수도 있다는 단점이 있다. 이를 최소화하기 위 하여 검사자를 1 명으로 고정시켜 그 검사자의 기준대로 평가하거나 ${ }^{19}$ 혹은 2 명의 검사자들이 일정한 기준에 따 라 $\mathrm{A}, \mathrm{B}, \mathrm{C}, \mathrm{D}$ 로 점수를 매기는 방법을 사용하기도 하였 다. ${ }^{20}$ 이와 관련된 가장 대표적인 평가 기준으로는 1971 년 Cvar와 Ryge이 언급한 United States Public Health Service (USPHS) 기준 중 “변연부 평가 항목”이 있는데 그 내용은 Table 1 과 같다. ${ }^{21}$

\section{2) 방사선 사진 검사법}

보철물의 평가는 시진, 촉진 이외에 방사선 사진 촬영 을 통한 검사도 가능하다. 방사선 사진 검사는 보철물의 경계 부위가 치은연하에 존재하여 탐침이나 육안으로 확 인할 수 없는 경우에 유용하다. 특히, 보철물이 과도한 길 이의 변연을 가지는 경우에 지대치의 마진 부위가 치은 연하에 존재하면 탐침 검사법이나 인상채득법으로는 발 견이 불가능하다. 또한, 보철물의 변연이 짧게 제작되어 지대치의 마진까지 충분히 연장되지 못한 경우에도 탐침 이용법이나 인상채득법으로 발견하지 못할 수 있으나, 방사선 사진 촬영법에서는 발견이 용이하다. ${ }^{22}$ 그 밖에도 방사선 사진은 남아있는 시멘트나 인상재를 확인할 수 있으며, 치조골과 보철물 사이의 위치 관계 및 생물학적

Table 1. The first criteria for marginal adaptation

Code Word

Alfa (A) The explorer does not "catch" when drawn across the restoration-tooth margin either from tooth to restoration or from restoration to tooth. If a "catch" exists, there is no visible crevice along the periphery of the restoration. The edge of the restoration appears to adapt closely to the tooth structure along the entire periphery of the restoration.

Bravo (B) The explorer does "catch" and there is visible evidence of a crevice into which the explorer will penetrate, indicating that the edge of the restoration does not closely adapt to the tooth structure. The dentin or base is not exposed, and the restoration is not mobile, fractured, or missing in part or in toto.

Charlie (C) The explorer penetrates into crevice indicating that a space exists between the restoration and the tooth structure. The dentin or the base is exposed at the periphery, but the restoration is not mobile, fractured, or missing in part or in toto.

Delta (D) The restoration is mobile, fractured, or missing in part or in toto.

Oscar Marginal adaptation cannot be assessed due to an excess of restorative material at the margin. 
폭경 길이를 확인하여 보철물의 예후를 평가하는데 용이 하다는 장점이 있다. ${ }^{23}$ 하지만 이 방법은 치아 근원심 부 위, 즉 보철물의 인접면 변연 부위만 확인이 가능하며 협 설측 변연 부위는 확인할 수 없다. 또한 촬영 각도에 따 라 획득되는 영상이 다르므로 절대적인 변연 간격의 수치 나 오차의 양을 확인하는 것은 불가능하고, 금속 보철물 인 경우에는 보철물의 내면을 전혀 확인할 수 없는 단점 이 있다. ${ }^{24}$ 방사선 사진 검사법을 이용할 경우 평행촬영법 을 통한 영상의 표준화가 필요하며, 높은 해상도를 가진 장비가 우선되어야 할 것이다.

\section{3) 인상채득법}

인상채득법을 통한 변연 부위의 평가는 1980년 Cardash 등에 의해 당시 "Silicone Putty Wash impression" 방법이 라는 이름으로 처음 소개되었다. 일단 보철물이 장착된 지대치를 퍼티를 이용하여 인상채득을 한 뒤, 흐름성이 좋은 실리콘 인상재로 한번 더 인상채득을 하여 보철물 의 변연 부위에 오차가 있는 경우 그 부위로 실리콘 인상 재가 흘러 들어가서 경화되는 원리를 이용한 것이다. Fig. 2는 실리콘을 이용한 인상채득법의 모식도를 보여준다.

임상에서 가장 대표적으로 사용되는 세 가지 방법인 탐 침 검사법, 방사선 사진 검사법, 인상채득법을 비교한 실험 에서 특별한 경우를 제외하고는 인상채득법을 통한 변연 부 평가가 가장 우수하게 나타나는 것으로 확인되었다. ${ }^{22}$

\section{2. 실험실 평가법(in vitro)}

임상적 평가 방법은 실제 자연치 지대치와 보철물의 관 계를 직접적으로 비교하는 방법이다. 반면, 실험실 평가 방법은 지대치 모양을 복제한 마스터 모형과 이를 통해
제작한 보철물의 관계를 비교하여 연구 목적에 따라 어 떤 결과를 보이는지 정밀하게 확인하기 위한 방법이다. 여기에는 보철물과 마스터 모형 사이의 공간을 직접적으 로 계측하는 직접 측정법이 있고, 내면 공간을 실리콘 인 상재로 복제하거나 마이크로 CT로 촬영한 단면 영상을 이용하여 측정하는 간접 측정법이 있다. 직접 측정법은 가장 직관적인 방법으로 오래 전부터 실험에 이용되었던 방법이며, 간접 측정법에 비해 비교적 정확도가 떨어지고 측정과 평가에 있어서 여러 가지 한계점이 있다.

\section{1) 직접 측정법}

(1) 변연부 측정법(Direct view technique)

변연부 측정법은 마스터 모형에 보철물을 시적하여 합 착시킨 후, 변연 부위의 오차를 직접 고해상도 현미경으 로 보고 분석하는 방법이다. 보철물을 부착하는 과정 이 외에는 별도의 다른 과정이 필요 없기 때문에 시간과 비 용이 가장 절약되는 장점이 있으며, 그만큼 부가적인 오 차 발생 확률이 줄어든다는 점이 다른 방법에 비해 유리 하다고 할 수 있다. 하지만 이 방법은 고해상도 현미경으 로 관찰해야 하므로 실험실 평가법으로만 가능하고 내 면 간격의 측정이 불가능하며, 치아와 색깔이 비슷한 시 멘트를 사용할 경우 치아와 시멘트 경계부에서 구별이 어렵다는 단점이 있다. 또한, 측정 시 변연 부위 중 어느 지점을 선택해야 하는가를 결정해야 하는데 측정 부위 마다 수치의 편차가 클 수 있어서 집단의 표본 수에 따 라 결과가 상이하게 나올 수 있다. Groten 등에 의하면 최소 50 개 이상의 지점을 대상으로 조사를 해야 변연 간 격의 정의에 따른 편차나 시멘트 합착 상태에 의한 오차 를 최소화하는 통계를 얻을 수 있다고 하였다. ${ }^{25}$ 뿐만 아

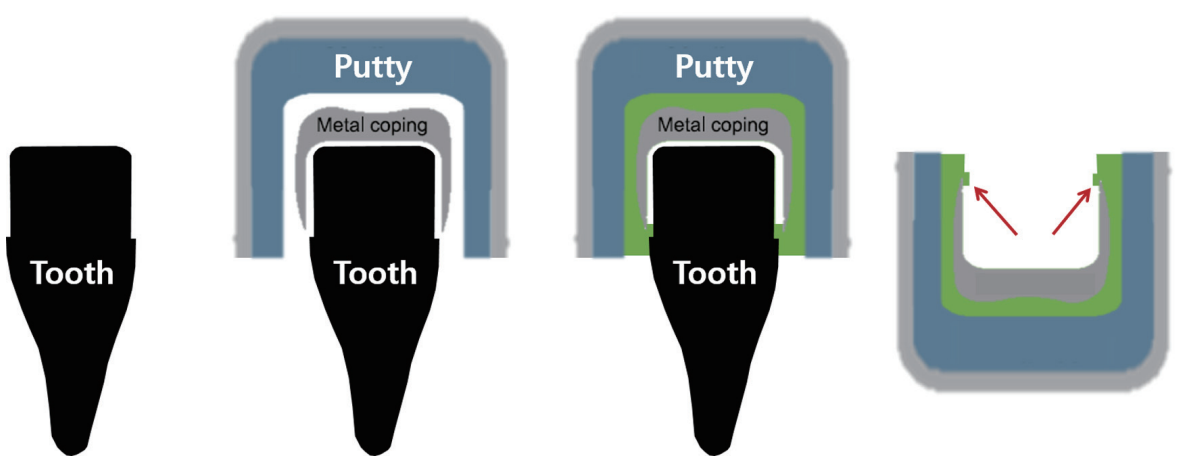

Fig. 2. The schematic of silicone putty wash impression. 
니라 이 방법의 가장 큰 문제는 투사 각도에 따른 오차 (projection error)이다. 관찰하는 각도에 따라 변연 간격 의 수치가 상대적으로 달라질 수 있기 때문이다. 변연부 측정법은 일반적으로 광학현미경이나 전자현미경으로 측정하는데, 1997년 Groten 등의 실험에서는 광학현미 경과 전자현미경(SEM)으로 변연부 오차를 측정한 결과 를 비교하여 둘 사이에 유의할만한 차이가 없음을 확인 하였다. ${ }^{26}$ 최근에는 입체 현미경(stereomicroscope)이나 고성능 디지털 현미경을 통한 영상을 바탕으로 디지털 프로그램 상에서 변연 오차를 측정하는 방법으로 변화하 고 있다. ${ }^{27}$

(2) 절단면 측정법(Cross-sectioning technique)

절단면 측정법은 마스터 모형에 보철물을 시적하여 합 착시킨 후 내면 공간 및 변연 공간을 측정하기 위해 시편 의 원하는 부위를 절단하고 절단면을 현미경으로 확인하 여 계측하는 방법이다. 변연 간격만 확인할 수 있는 다른 방법들에 비해서 이 방법은 변연 및 내면 공간을 모두 알 아보고자 할 때 유용하다. 브릿지 연결부와 같은 방해가 되는 구조물에 관계없이 원하는 부위는 어디든지 절단하 여 확인할 수 있는 장점이 있지만, 아무리 조심스럽게 절 단하더라도 시편을 절단하는데 가해지는 힘에 의해 눈 에 보이지 않는 변형이 생길 수 있다는 단점이 있으면, 절 단하는 면이 한정되어 있기 때문에 여러 부위에서 측정할 수 없다는 한계가 있다. 그리고 한번 절단을 시행하면 그 시편을 재사용할 수 없으므로 장기적인 결과의 비교나 분석이 어렵고, 비용과 시간적인 면에서 불리하다. 절단 된 시편은 보통 변연 부위, 변연과 지대치 축벽의 이행부, 지대치 축벽 부위, 지대치 교합면 부위에서 측정하며, 광 학현미경 상에서 50 배율로 확대하여 관찰하는 것이 일반 적이다. ${ }^{28}$

\section{2) 간접 측정법}

(1) 실리콘 복제 측정법(Replica technique)

실리콘 복제 측정법은 마스터 모형과 보철물 사이에 실리콘 인상재를 넣고 균일하게 시적시켜 인상재가 경화 되면 내면 공간의 모양이 실리콘에 그대로 인기되는 원리 를 이용한 것이다. ${ }^{29-32}$

이 방법은 1993년 인레이 적합도를 알아보는 실험에서 처음으로 사용된 방법 ${ }^{15}$ 에서 발전하여 점차 보철물의 적 합도를 알아보는 가장 대표적인 방법으로 발전해왔다.
흐름성이 좋은 실리콘 인상재(light body)는 단독으로 제 거하면 변형될 위험이 높기 때문에 강도가 높은 실리콘 인상재(medium or heavy body)를 외측이나 내측에서 보 강하여 분리한 후, 필요한 부분의 두께를 측정하는 방법 으로 사용되고 있다. 비용과 시간이 비교적 적게 들고 마 스터 모델이 보존 가능하므로 반복적인 측정이 가능하다 는 장점이 있지만, 미세한 부분에서 실리콘이 찢어지거나 변형될 수 있다는 점과 실리콘 상에서 지대치의 마진과 보철물의 변연을 구별하기 어렵다는 점이 단점으로 지적 되고 있다. 실리콘 인상재의 두께를 측정하는 방법은 인 상재를 절단하여 원하는 부위만 측정하는 2 차원적인 방 법 ${ }^{20-37}$ 과 모형 스캐너를 통해 인상재를 전부 스캔하여 3 차원적으로 측정하는 3 차원적인 방법으로 나눌 수 있 다. ${ }^{38-41}$ 실리콘 인상재를 절단하여 2차원적으로 측정하는 방법은 앞서 살펴본 절단면 측정법과 마찬가지로 절단 부위가 한정되어 있기 때문에 여러 곳에서 측정이 불가하 다는 한계가 있다. 뿐만 아니라 절단하는 각도에 따라 측 정 두께가 달라질 수 있다는 점을 주의해야한다. Fig. 3은 2 차원적인 방법으로 실리콘 인상재를 이용하여 지대치의 마진과 보철물의 변연을 인상재의 두께 측정으로 확인하 는 과정을 보여준다. 모형 스캐너를 통한 3 차원적인 분석 은 전반적인 내면 간격의 양상을 확인할 수 있는 장점이 있지만, 변연 간격을 측정할 때에는 치아나 보철물과 같 은 주위 구조물의 형상이 없기 때문에 측정 지점을 명확 하게 설정할 수 없다는 단점이 있다. 또한, 아직까지 실리 콘 인상재의 얇은 부위를 정확하게 인식할 정도로 스캐 너 해상도가 발전하지 못해서 실제와 다른 스캔 이미지 가 오차로 작용할 수 있는 가능성도 한계로 지적되고 있 다. Fig. 4는 모형 스캐너를 통해 3차원적으로 인상재의 두께를 측정하여 지대치의 마진과 보철물사이의 변연을 확인하는 과정을 보여준다.

\section{(2) 마이크로 CT 측정법 (Micro-CT)}

마이크로 CT 측정법은 방사선을 이용한 비파괴적인 측정 방법으로 원하는 부위에서 2 차원 또는 3 차원 영상 을 획득할 수 있다. 수많은 단면 영상을 얻을 수 있기 때 문에 원하는 지점에서의 수치를 평가할 수도 있고, 단면 영상을 합쳐 3 차원적으로 재구성하면 보철물의 전체적인 적합도 결과도 함께 평가할 수 있다는 장점이 있다. 이 방 법의 가장 큰 단점은 방사선을 이용하므로 금속성 인공 물에 대한 장해음영(artifact)이 나타난다는 점이다. 따라 서 금속으로 된 보철물 평가에는 적용하기 힘들다. 또한, 

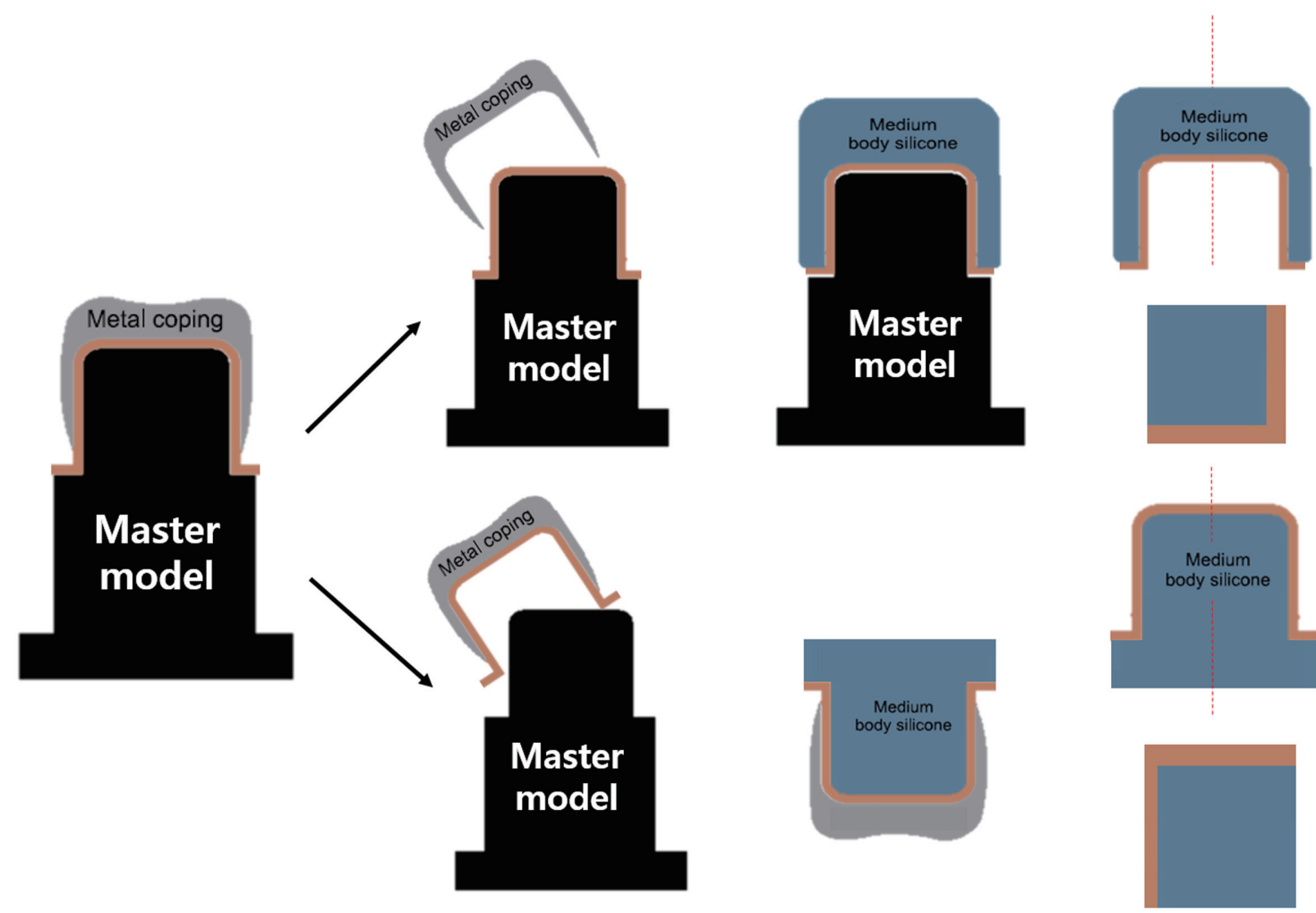

Fig. 3. 2-D measurement of the thickness of the film with outer or inner coating using heavy body silicone.
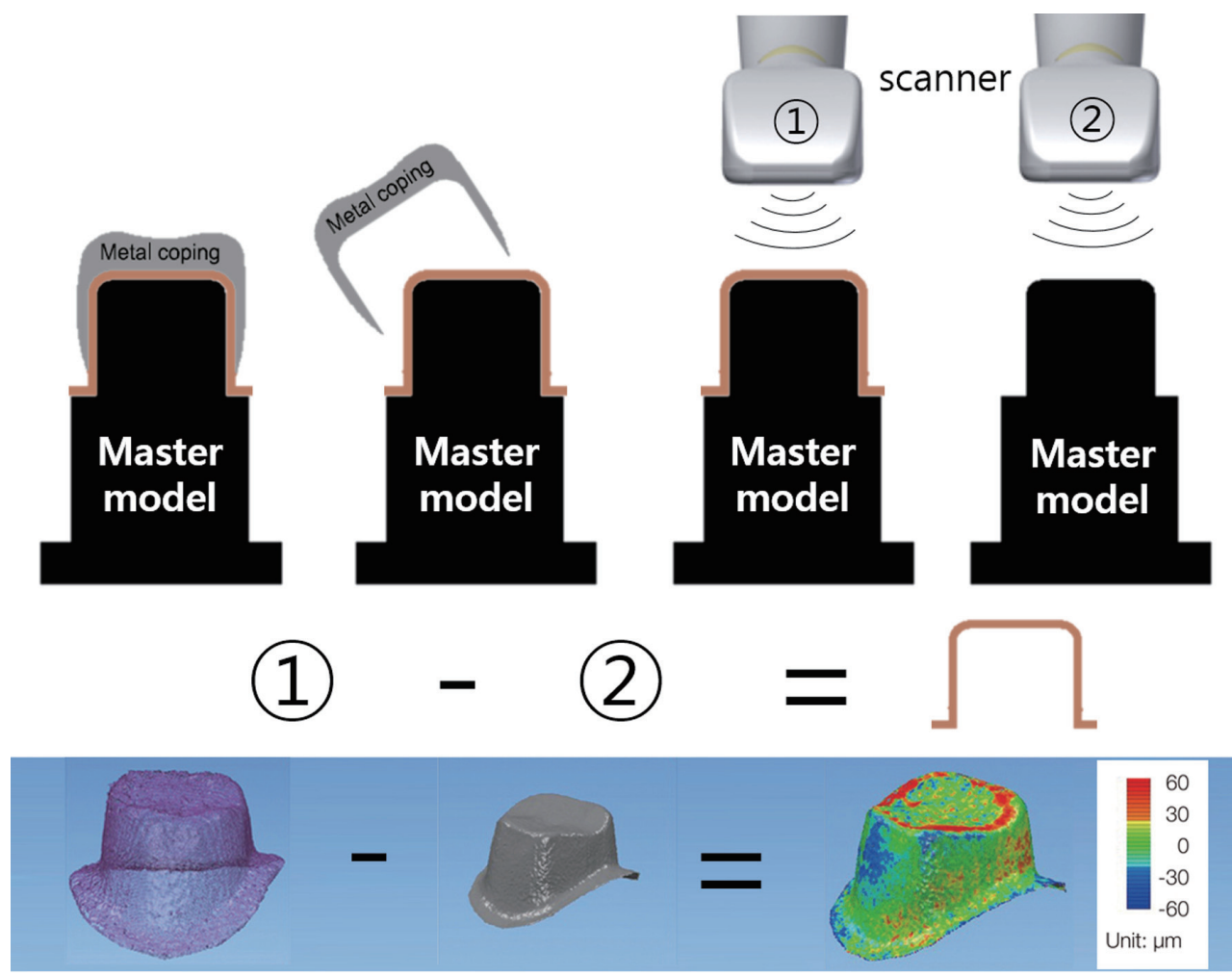

Fig. 4. 3-D measurement of the thickness of the film using model scanner. 
똑같은 방사선 흡수 계수를 가진 서로 다른 두 물질이 접 촉해 있을 때 이를 분리해낼 수 없다는 점도 주의해야 한 다. 그리고 시간과 비용이 비교적 많이 든다는 점과 광학 현미경이나 전자현미경이 각각 $300 \mathrm{~nm}, 0.25 \mathrm{~nm}$ 정도의 나노 단위 분해능을 가진 것에 비해 마이크로 CT는 1.8 $\mu \mathrm{m}$ 의 분해능으로 현미경보다 조금 덜 선명한 확대영상 을 제공한다는 점도 한계라고 할 수 있다. ${ }^{42-45} \mathrm{Fig} .5$ 는 마 이크로 CT 측정을 통하여 보철물의 적합도를 평가하는 모식도를 나타내고 있다.

\section{(3) 조면계 측정법(Profilometry)}

Fig. 6은 조면계를 이용하여 보철물의 변연오차를 측정 하는 방법을 보여준다. 조면계(Profilometer)는 본래 표
면의 거칠기를 측정하는 장비로 변연부 오차가 존재하 는 부위에서 경계부가 매끄럽게 이어지지 않고 불규칙한 표면을 갖는 특징을 이용한 것이다. 이 방법은 비파괴적 인 방법이며, 변연 부위를 연속적으로 측정할 수 있기 때 문에 기존의 다른 방법과 달리 보철물의 전체적인 절대변 연간극을 추정하는데 유용하다. 하지만 이 방법은 연속 적인 결과를 바탕으로 변연 상태를 간접적으로 추론하는 것일 뿐, 해당 부위의 자세한 영상을 얻지 못하므로 측정 시에 생기는 오류를 수정할 수 없는 단점이 있다. 예를 들 어 수직적으로 과도한 변연 길이를 갖는 보철물이 지대 치와 매끄럽게 이행된다면, 이런 경우에 이 장비는 변연 부 오차가 없는 것으로 간주하게 되므로 실험결과에 오 류가 생길 가능성이 있다. ${ }^{46,47}$
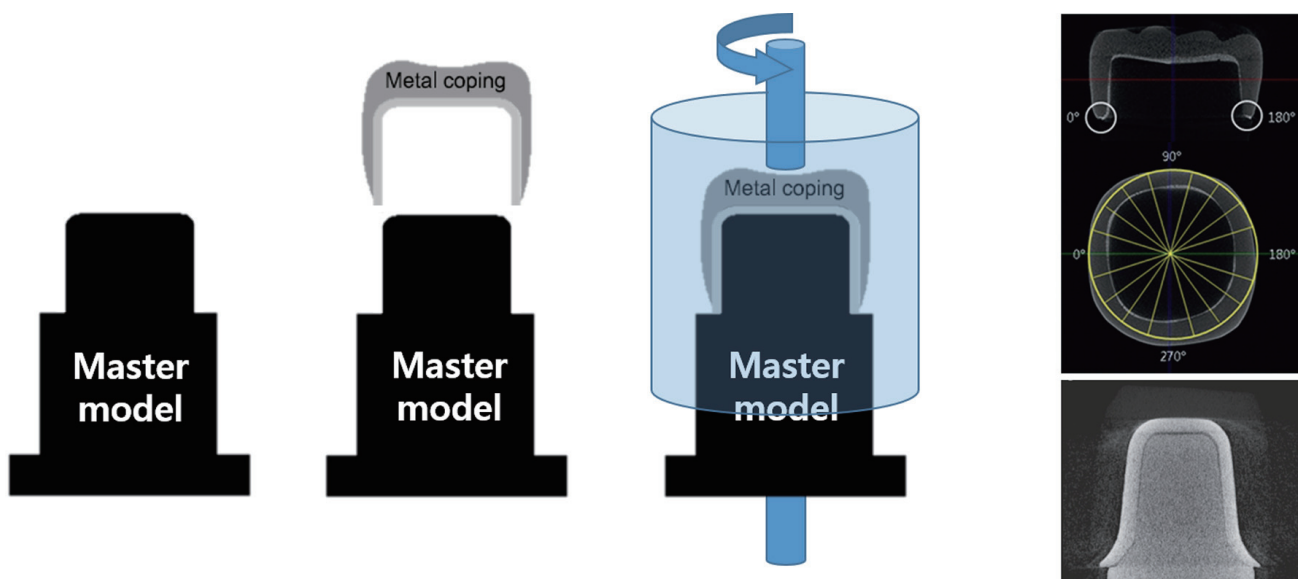

Fig. 5. The schematic of micro-CT measurement and CT image.
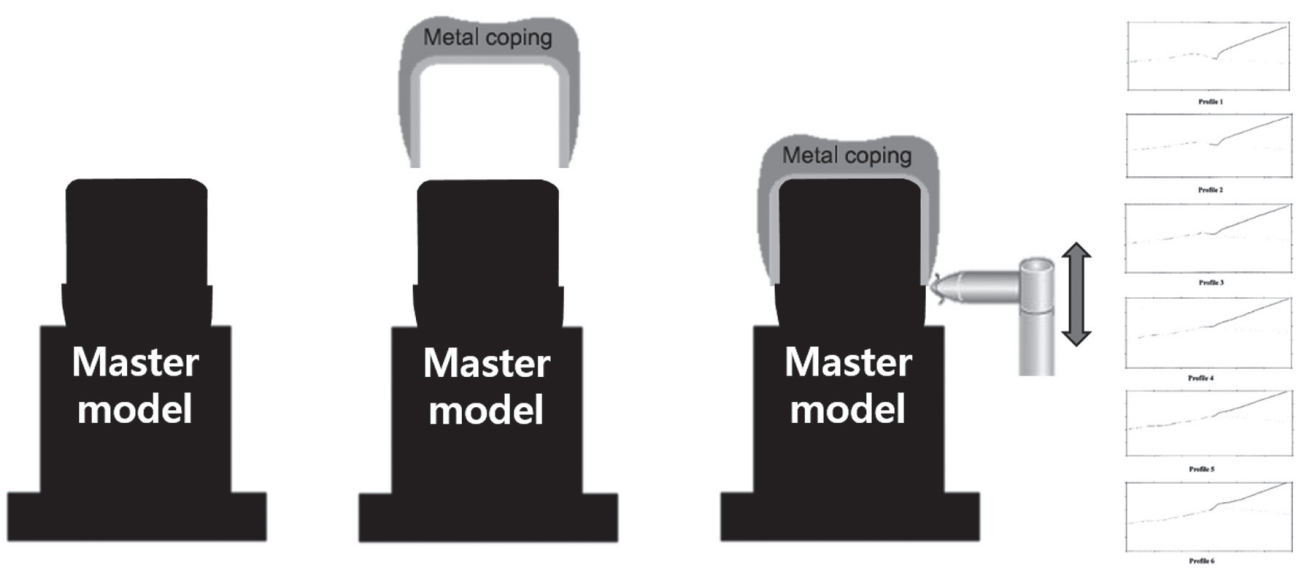

Fig. 6. The schematic of measurement using profilometry. 


\section{결론}

보철물의 적합도 평가 방법은 여러 가지 기준에 의해 분류할 수 있다. 보철물의 제작 방법(기존의 방식 또는 디지털 방식), 보철물의 재료(금속관 또는 전부도재관 등), 지대치의 마진 형태(chamfer 또는 shoulder), 보철물 의 완성도(코핑 단계 또는 완성 단계), 보철물 시적 대상 (실제 지대치 또는 마스터 모형), 시멘트 합착 여부(합착 전 또는 합착 후), 보철물 내면 조정 여부 등 많은 기준에 따라 구분이 가능하다. ${ }^{48}$ 또한, Table 2 에서 보는 바와 같 이 2013년 Nawafleh 등은 여러 가지 방법으로 보철물의 적합도를 평가한 183 개의논문을 찾아서 조사한 결과, 직 접 측정하는 방법인 변연부 측정법과 절단면 측정법이 총 $70 \%$ 이상으로 가장 많았고, 간접적으로 측정하는 실리 콘 복제 측정법이 $20 \%$ 를 나타내어 그 다음으로 자주 사 용되었다고 발표하였다. ${ }^{49}$ 이는 역사가 오래된 방법일수 록 많은 빈도로 사용된 것으로 추정되며, 시간과 비용이 적게 들어가는 변연부 측정법이 가장 선호된 것으로 판 단된다. 반면에 최근 새롭게 개발된 평가방법일수록 발 표된 연구 논문이 적은 것은 당연한 결과라고 할 수 있을 것이다.

본 논문에서는 보철물의 적합도를 평가하는 방법으로 크게 임상적 평가법(in vivo)과 실험실 평가법(in vitro)으 로 나누어 비교해 보았다. 임상적 평가법에는 탐침 검사 법, 방사선 사진 검사법, 인상채득법이 있고, 실험실 평가 법은 다시 직접 측정법과 간접 측정법으로 분류하여 직 접 측정하는 변연부 측정법과 절단면 측정법, 간접 측정 하는 실리콘 복제 측정법과 마이크로 CT 측정법, 그리고 조면계 측정법이 있으며, 각각의 평가방법에 대해 본 논 문에서 자세히 알아보았다. 본 논문에서 소개한 다양한

Table 2. Analysis of marginal adaptation reported by various methods

\begin{tabular}{lc}
\hline \multicolumn{1}{c}{ Methods } & Number of papers $(\%)$ \\
\hline Direct-view technique & $87(47.5 \%)$ \\
Cross-sectioning technique & $43(23.5 \%)$ \\
Replica technique & $37(20.2 \%)$ \\
Profile projector & $7(3.8 \%)$ \\
Digimatic micrometer & $2(1.2 \%)$ \\
Micro-CT & $3(1.6 \%)$ \\
Combination of two methods & $4(2.2 \%)$ \\
Total & $183(100 \%)$ \\
\hline
\end{tabular}

적합도 평가법을 바탕으로 하여 시간이 흐를수록 기술 이 발전하고 있으며, 기존 방법들이 가지고 있는 단점들 을 극복하고, 보다 정확도가 높은 다양한 새로운 실험 방 법들이 계속 개발되고 추세이다. 그러므로 이런 다양한 적합도 평가 방법들의 장, 단점을 숙지하여 알맞은 디자 인으로 실험을 한다면 보철물의 적합도를 더욱 정밀하게 평가할 수 있을 것으로 기대된다. 또한, 이와 같이 현재 사용되고 있는 보철물의 적합도에 대한 평가방법들을 정 확히 숙지하고 이해하는 것은 보철물을 환자에게 식립하 기 전에 보다 적확한 형태의 보철물 제작을 가능하게 하 여 환자에 대한 보철물 식립의 실패가 발생하지 않게 하 는 척도가 될 것으로 생각한다.

\section{Acknowledgements}

본 연구는 산업통상자원부의 재원으로 산업핵심기술 개발사업의 지원에 의하여 이루어진 것임(No.10062402).

\section{ORCID}

Se-Wook Pyo http://orcid.org/0000-0003-1835-8302

Jun-Jae Lee http://orcid.org/0000-0002-5496-0168

Jung-Suk Han http://orcid.org/0000-0002-9439-1465

Young-Jun Lim http://orcid.org/0000-0003-2504-9671

\section{References}

1. Hung SH, Hung KS, Eick JD, Chappell RP. Marginal fit of porcelain-fused-to-metal and two types of ceramic crown. J Prosthet Dent 1990;63:26-31.

2. McLean JW, von Fraunhofer JA. The estimation of cement film thickness by an in vivo technique. $\mathrm{Br}$ Dent J 1971;131:107-11.

3. Schwartz NL, Whitsett LD, Berry TG, Stewart JL. Unserviceable crowns and fixed partial dentures: life-span and causes for loss of serviceability. J Am Dent Assoc 1970;81:1395-401.

4. Grasso JE, Nalbandian J, Sanford C, Bailit H. Effect of restoration quality on periodontal health. J Prosthet Dent 1985;53:14-9.

5. Walton JN, Gardner FM, Agar JR. A survey of crown and fixed partial denture failures: length of service and reasons for replacement. J Prosthet 
Dent 1986;56:416-21.

6. Bader JD, Rozier RG, McFall WT Jr, Ramsey DL. Effect of crown margins on periodontal conditions in regularly attending patients. J Prosthet Dent 1991;65:75-9.

7. Holmes JR, Bayne SC, Holland GA, Sulik WD. Considerations in measurement of marginal fit. J Prosthet Dent 1989;62:405-8.

8. A.D.A. specification No. 8 for dental zinc phosphate cement. Chilwa Kijae Hakhoe Chi 1967;2:647.

9. Ostlund LE. Cavity design and mathematics: their effect on gaps at the margins of cast restorations. Oper Dent 1985;10:122-37.

10. Sulaiman F, Chai J, Jameson LM, Wozniak WT. A comparison of the marginal fit of In-Ceram, IPS Empress, and Procera crowns. Int J Prosthodont 1997;10:478-84.

11. McLean JW, von Fraunhofer JA. The estimation of cement film thickness by an in vivo technique. $\mathrm{Br}$ Dent J 1971;131:107-11.

12. Gulker I. Margins. N Y State Dent J 1985;51:213-5, 217.

13. Moldovan O, Rudolph H, Quaas S, Bornemann G, Luthardt RG. Internal and external fit of CAMmade zirconia bridge frameworks-a pilot study. Dtsch Zahnärztl Z 2006;61:38-42.

14. Sorensen JA. A standardized method for determination of crown margin fidelity. J Prosthet Dent 1990;64:18-24.

15. Molin M, Karlsson S. The fit of gold inlays and three ceramic inlay systems. A clinical and in vitro study. Acta Odontol Scand 1993;51:201-6.

16. Pelekanos S, Koumanou M, Koutayas SO, Zinelis S, Eliades G. Micro-CT evaluation of the marginal fit of different In-Ceram alumina copings. Eur J Esthet Dent 2009;4:278-92.

17. Luthardt RG, Bornemann G, Lemelson S, Walter MH, Hüls A. An innovative method for evaluation of the 3-D internal fit of CAD/CAM crowns fabricated after direct optical versus indirect laser scan digitizing. Int J Prosthodont 2004;17:680-5.

18. Hickel R, Roulet JF, Bayne S, Heintze SD, Mjör IA, Peters M, Rousson V, Randall R, Schmalz G, Tyas M, Vanherle G. Recommendations for conducting controlled clinical studies of dental restorative materials. Clin Oral Investig 2007;11:5-33.

19. Karlsson S. A clinical evaluation of fixed bridges, 10 years following insertion. J Oral Rehabil 1986; 13:423-32.

20. Akbar JH, Petrie CS, Walker MP, Williams K, Eick JD. Marginal adaptation of Cerec 3 CAD/CAM composite crowns using two different finish line preparation designs. J Prosthodont 2006;15:155-63.

21. Cvar JF, Ryge G. Reprint of criteria for the clinical evaluation of dental restorative materials. 1971. Clin Oral Investig 2005;9:215-32.

22. Assif D, Antopolski B, Helft M, Kaffe I. Comparison of methods of clinical evaluation of the marginal fit of complete cast gold crowns. J Prosthet Dent 1985;54:20-4.

23. Fattahi F, Giti R, Torabi K. Marginal assessment of crowns by the aid of parallel radiography. J Dent Mater Tech 2015;4:29-36.

24. Liedke GS, Spin-Neto R, Vizzotto MB, Da Silveira PF, Silveira HE, Wenzel A. Diagnostic accuracy of conventional and digital radiography for detecting misfit between the tooth and restoration in metalrestored teeth. J Prosthet Dent 2015;113:39-47.

25. Groten M, Axmann D, Pröbster L, Weber H. Determination of the minimum number of marginal gap measurements required for practical in-vitro testing. J Prosthet Dent 2000;83:40-9.

26. Groten M, Girthofer S, Pröbster L. Marginal fit consistency of copy-milled all-ceramic crowns during fabrication by light and scanning electron microscopic analysis in vitro. J Oral Rehabil 1997;24: 871-81.

27. Euán R, Figueras-Álvarez O, Cabratosa-Termes J, Oliver-Parra R. Marginal adaptation of zirconium dioxide copings: influence of the CAD/CAM system and the finish line design. J Prosthet Dent 2014;112:155-62.

28. Beuer F, Naumann M, Gernet W, Sorensen JA. Precision of fit: zirconia three-unit fixed dental prostheses. Clin Oral Investig 2009;13:343-9.

29. Tinschert J, Natt G, Mautsch W, Spiekermann H, Anusavice KJ. Marginal fit of alumina-and zirconiabased fixed partial dentures produced by a CAD/ CAM system. Oper Dent 2001;26:367-74. 
30. Kokubo Y, Nagayama Y, Tsumita M, Ohkubo C, Fukushima S, Vult von Steyern P. Clinical marginal and internal gaps of In-Ceram crowns fabricated using the GN-I system. J Oral Rehabil 2005;32:7538.

31. Laurent M, Scheer P, Dejou J, Laborde G. Clinical evaluation of the marginal fit of cast crownsvalidation of the silicone replica method. J Oral Rehabil 2008;35:116-22.

32. Rahme HY, Tehini GE, Adib SM, Ardo AS, Rifai KT. In vitro evaluation of the "replica technique" in the measurement of the fit of Procera crowns. J Contemp Dent Pract 2008;9:25-32.

33. Reich S, Kappe K, Teschner H, Schmitt J. Clinical fit of four-unit zirconia posterior fixed dental prostheses. Eur J Oral Sci 2008;116:579-84.

34. Kohorst P, Brinkmann H, Li J, Borchers L, Stiesch M. Marginal accuracy of four-unit zirconia fixed dental prostheses fabricated using different computer-aided design/computer-aided manufacturing systems. Eur J Oral Sci 2009;117:319-25.

35. Kohorst P, Brinkmann H, Dittmer MP, Borchers L, Stiesch M. Influence of the veneering process on the marginal fit of zirconia fixed dental prostheses. J Oral Rehabil 2010;37:283-91.

36. Kohorst P, Junghanns J, Dittmer MP, Borchers L, Stiesch M. Different CAD/CAM-processing routes for zirconia restorations: influence on fitting accuracy. Clin Oral Investig 2011;15:527-36.

37. Colpani JT, Borba M, Della Bona A. Evaluation of marginal and internal fit of ceramic crown copings. Dent Mater 2013;29:174-80.

38. Luthardt RG, Bornemann G, Lemelson S, Walter $\mathrm{MH}$, Hüls A. An innovative method for evaluation of the 3-D internal fit of CAD/CAM crowns fabricated after direct optical versus indirect laser scan digitizing. Int J Prosthodont 2004;17:680-5.

39. Moldovan O, Luthardt RG, Corcodel N, Rudolph H. Three-dimensional fit of CAD/CAM-made zirconia copings. Dent Mater 2011;27:1273-8.

40. Kim KB, Kim JH, Kim WC, Kim HY, Kim JH. Evaluation of the marginal and internal gap of metal-ceramic crown fabricated with a selective laser sintering technology: two- and three-dimensional replica techniques. J Adv Prosthodont 2013;5: 179-86.

41. Kuhn K, Ostertag S, Ostertag M, Walter MH, Luthardt RG, Rudolph H. Comparison of an analog and digital quantitative and qualitative analysis for the fit of dental copings. Comput Biol Med 2015; 57:32-41.

42. Pelekanos S, Koumanou M, Koutayas SO, Zinelis S, Eliades G. Micro-CT evaluation of the marginal fit of different In-Ceram alumina copings. Eur J Esthet Dent 2009;4:278-92.

43. Borba M, Miranda WG Jr, Cesar PF, Griggs JA, Bona AD. Evaluation of the adaptation of zirconia-based fixed partial dentures using micro-CT technology. Braz Oral Res 2013;27:396-402.

44. Pimenta MA, Frasca LC, Lopes R, Rivaldo E. Evaluation of marginal and internal fit of ceramic and metallic crown copings using $\mathrm{x}$-ray microtomography (micro-CT) technology. J Prosthet Dent 2015; 114:223-8.

45. Kim JH, Jeong JH, Lee JH, Cho HW. Fit of lithium disilicate crowns fabricated from conventional and digital impressions assessed with microCT. J Prosthet Dent 2016 Jul 13. doi: 10.1016/ j.prosdent.2016.03.028. [Epub ahead of print]

46. Mitchell CA, Pintado MR, Douglas WH. Nondestructive, in vitro quantification of crown margins. J Prosthet Dent 2001;85:575-84.

47. Limkangwalmongkol P, Kee E, Chiche GJ, Blatz MB. Comparison of marginal fit between all-porcelain margin versus alumina-supported margin on Procera Alumina crowns. J Prosthodont 2009;18: 162-6.

48. Contrepois M, Soenen A, Bartala M, Laviole O. Marginal adaptation of ceramic crowns: a systematic review. J Prosthet Dent 2013;110:447-454.

49. Nawafleh NA, Mack F, Evans J, Mackay J, Hatamleh MM. Accuracy and reliability of methods to measure marginal adaptation of crowns and FDPs: a literature review. J Prosthodont 2013;22:419-28. 


\section{고정성 보철물의 내면 및 변연적합도를 평가하는 방법에 대한 고찰}

\section{표세욱, 이준재, 한중석, 임영준*}

서울대학교 치의학대학원 치과보철학교실

본 논문은 기존에 선행되었던 연구들을 바탕으로 고정성 보철물의 내면 및 변연적합도를 평가하는 여러 가지 방법에 관 하여 정리하였으며, 각 방법에 대한 장, 단점에 대해 언급하였다. 보철물의 적합도를 평가하는 방법은 크게 임상적 평가 법과 실험실 평가법으로 분류할 수 있다. 임상적 평가법에는 탐침 검사법, 방사선 사진 검사법, 인상채득법이 있으며, 실 험실 평가법에는 현미경을 이용하는 변연부 측정법, 절단면 측정법, 실리콘 복제 측정법, 그리고 마이크로 CT나 조면계 를 사용하여 측정하는 방법 등이 있다. 최근 스캐닝 기법이 발전하면서 내면 및 변연적합도를 3차원적으로 평가하는 것 이 가능해졌으며, 앞으로 측정법 및 분석법의 개발에 따라 보철물의 적합도 평가가 더욱 간편해지고 효과적으로 변화할 것이라 생각된다.

(구강회복응용과학지 2016;32(3):158-68)

주요어: 변연적합도; 내면적합도; 보철물 시적평가; 적합도 평가법 